\title{
Communication of Character Education through Special Purwakarta 7 Days of Education (7 Poe Atikan) (Qualitative Descriptive Study on Character Education in Purwakarta Regency)
}

\author{
Susie Perbawasari ${ }^{1}$, Susanne Dida ${ }^{2}$, Aat Ruchiat Nugraha ${ }^{3}$, Achwan Noorlistyo Adi ${ }^{4}$ \\ \{susie.perbawasari@unpad.ac.id ${ }^{1}$ \} \\ Universitas Padjadjaran, Indonesia ${ }^{1,2,3,4}$
}

\begin{abstract}
Today, character education becomes the spotlight in the world of education in Indonesia, as well as in Purwakarta Regency. Purwakarta Regency government which has built the character and identity of Sundanese cultural values also contributes to encourage and develop character education in Purwakarta Regency that is in line with the identity of Purwakarta Regency itself. The objectives of this study are to reveal how the Government of Purwakarta Regency establish character education that is oriented towards Special Purwakarta Sundanese cultural values and to reveal how it is implemented. This study uses a qualitative method by collecting data through interview, observation, and literature study. Key informants in this study are the Head of the Primary Education Division, Purwakarta Education Department and 3 well-performed teachers in Purwakarta Regency. The results of this study indicate that the Government of Purwakarta Regency created a program of Special Purwakata 7 Days of Education which is in line with the 2013 Curriculum. Seven Education Days has several important values in shaping the character of students in Purwakarta Regency. These values are communicated with a theme in each day, namely Monday, Ajeg Nusantara; Tuesday, Mapag di Buana; Wednesday, Maneuh di Sunda; Thursday, Nyanding Wawangi; Friday, Nyucikeun Diri; Saturday and Sunday, Betah di Imah.
\end{abstract}

Keywords: Purwakarta Regency, Character Education, Educational Communication, Special Purwakarta Education.

\section{Introduction}

Today, the development of technology in the process of student socialization has a significant influence on the way they behave in school and the surrounding environment. Of course, the influence of this technological development has positive and negative values. The influence of the environment and also this technology cannot be dammed. Humans will always follow the existing path, and its influence is enormous on social and cultural relations in society $[1]$.

Character education is essential for every student to increase children's awareness of good behavior. Of course, character education provides direction and perspective for each student to build and hone back the attitudes and values that are owned by each individual. Character education itself is defined as education that is rebuilt in the context of strengthening the identity 
of every Indonesian in order to become virtuous individuals and have a sensitivity to goodness [2].

To shape character education in order to maintain cultural treasures during the conditions of social life and also the development of existing technology, the government surely pay their attention and make efforts to build character through education. The Government of Purwakarta Regency likewise conducts it. The Purwakarta Regency Government also see this as an opportunity to instill cultural values that have been developed into the Purwakarta regional identity. H. Dedi Mulyadi, the Regent of Purwakarta at that time, also conducted studies with his staff in the education and community service in 2012. As the results of the study, the character education was formed, it was called Tujuh Poe Atikan Purwakarta Istimewa which is interpreted as Special Purwakarta Seven Days of Education. The socialization was also carried out in 2014. Every educational institution is obliged to deliver the program in every Monday flag ceremony.

"The Special 7 Poe Atikan program is a concrete manifestation of a character education policy that has been rolled out since mid-2014. In its application, the government applies the mathematical element and makes it philosophy in every learning in schools."1

Of course, to achieve the goal of character education, the relevant agency which is the Purwakarta Education Office, also formulates various things to make the implementation of the character education run effectively. One of them is by having a communication function. Communication is considered necessary in the delivery of character education itself. The teacher as the communicator certainly has a communication method so that Special Purwakarta 7 Days of Character Education can be aligned with the education curriculum used in Indonesia, namely the 2013 Curriculum. Based on this background, the researchers draw a focus of research that is how communication of character education is conducted through 7 Days of Character Education. The aim of this research is to find out and explain the communication of character education in Purwakarta Regency through 7 Days of Character education.

\section{Research Methods}

The method used in this study is a qualitative method that intends to understand about what is experienced holistically and descriptively by the research subjects, such as behavior, perception, motivation, action, and etc. In the form of words and language, in a particular scientific context and by utilizing various natural methods [3]. This study uses a descriptive approach. Descriptive studies themselves describe the actual state of the object which is being researched according to the actual situation at the time the research takes place [4]. The subjects in this study are the informants who meet the criteria: those who are directly involved in the implementation of Special Purwakarta 7 Days of Character Education; they are the Head of Basic Education Division of the Purwakarta Regency Education Office and three elementary school teachers who performs well in Purwakarta Regency in 2019. The data collection techniques used are through interviews, observation, and literature study.

${ }^{1}$ H. Purwanto, Head of Purwakarta Regency Education Office, accessed through http://disdik.purwakartakab.go.id/berita/detail/kadisdik-purwanto-paparkan-konteks-7-poe-atikanistimewa 


\section{Literature Review}

In the literature review, researchers emphasize more on the concepts of character education, Purwakarta 7 Days of Education, and effective communication. According to the Ministry of Education and Culture [5], character education is interpreted as education that develops the nation's character in students so that they have values and character, as members of society, and citizens who are religious, nationalist, productive and creative. Meanwhile, according to Ramli [6], he states that the purpose of character education is to shape the child's personality, so that he becomes a good human being, a citizen, and a good citizen of a society or nation. In general, it is translated as specific social value, which is heavily influenced by the culture of the people and nation.

The Regent of Purwakarta, Dedi Mulyadi, issued the Purwakarta Regent Regulation No. 69 of 2015 [7] which concerned on the Character Education, in which there are XIV Chapters and 35 articles. The formation of this program is due to the concern from Dedi Mulyadi regarding the current behavior of students who are considered to be not within reasonable limits, such as the many cases involving adolescents in brawls, smoking, and other forms of juvenile delinquency. This guideline has the purpose and goal of training students to be able to familiarize themselves with an orderly, independent, caring, and sensitive lifestyle towards the environment by applying the values introduced through the learning process at school.

The fundamental values in this education are guided by the value of Sundanese in accordance with the identity or branding carried out by the Purwakarta Regency Government. Education has become an essential element in building Purwakarta's identity so that the Sundanese values are applied to the character education. These values are: a) Monday Ajeg Nusantara; b) Tuesday Mapag Buana; c) Wednesday Maneuh in Sunda; d) Thursday is Nyanding Wawangi; e) Friday Nyucikeun Diri; f) Saturday-Sunday Betah di Imah.

\section{Results and Discussion}

Development in Purwakarta Regency in recent years has received more attention from the public. Purwakarta Regency itself has a strategic geographical location as the Pasundan Gate, bordering the Indonesian capital, Jakarta, and also the capital of West Java, Bandung. The direction of development policy in Purwakarta Regency itself is oriented to the excellence of education, health, agriculture, industry, trade, and services, as well as development based on religion and local wisdom values.

This particular character education, Special Purwakarta 7 Days of Education, is also in line with the mission of the Purwakarta Regency Government, which is to strengthen local values (local wisdom), both geographical, territorial, and capacity-intellectual. This has become part of efforts to increase local potential, both cultural, regional, local, as well as creating personal excellence, which has intellectual, emotional, and spiritual wisdom. So that it can form a generation of Purwakarta following the values: cageur (healthy), bageur (kind), bener (right), pinter (clever), and singer (introspective) [8].

The Special Purwakarta 7 Days of Education implements a program that consists of various aspects of content so that students can get to know local wisdom that is Sundanese culture which has also been used in daily life by the Purwakarta Regency government as the city identity. The 7 Poe Atikan program in Purwakarta is organized systematically related to character building 
for students who later able to compete, be moral, be polite and also be able to interact with the community.

The Special Purwakarta 7 Days of Character Education program is also the values of human behavior related to God Almighty, self, fellow human beings, the environment, and nationality manifested in thoughts, attitudes, feelings, words and deeds which are certainly based on religious norms, law, manners, culture and customs. This 7 Days of Character Education program can clearly be interpreted as a system of inculcating character values to school members which includes components of knowledge, awareness and actions to carry out these values.

In carrying out this program, all parties or components surely must run with good synergy, including the education components themselves. These components include curriculum content, learning and assessment processes, relationship quality, subject management, school management, and the implementation of co-curricular activities in schools. Thus, it is seen that there is a need for educational communication to deliver this program so that it can be implemented well [9].

\subsection{Communication of Character Education through Special Purwakarta 7 Education Days}

One way to communicate the character education is to integrate the learning system in each subject with the 7 Days of Character Education program. Learning materials relating to values and norms in each subject must be related to daily life. This is useful for students because the learning of character values does not only lay in the cognitive domain, but also touches on the affective and behavioral domains.

Purwakarta Regent Regulation [7], states that the Special Purwakarta 7 Days of Character Education include the following values: Ajeg Nusantara, Mapag Buana, Maneuh di Sunda, Nyanding Wawangi, Nyucikeun Diri, dan Betah di Imah. These values are then communicated through various means, both verbal and non-verbal communication. Communication carried out so that these values can be carried out properly adjusted to the days that have been regulated in the Purwakarta Regent Regulations. Communication education is as follows:

\subsubsection{Monday, Ajeg Nusantara}

These values are communicated through Scout uniforms worn by both students and teachers. Then the teachers explain each subject which then relates to the archipelago, both natural wealth to culture. Ajeg Nusantara itself has the meaning of Upholding the life of the nation and the homeland. Thus, students can have a high nationalist sense.

"Using scout clothing means practising physical and mental strength, because with a scout spirit, at least children can learn patriotism by providing an understanding of the importance of mutual cooperation, as does scouting". ${ }^{2}$

The Ajeg Nusantara program is in line with the Ministry of Education and Culture's goals related to character education which is able to create citizens who have a nationalist sense. This

\footnotetext{
${ }^{2}$ Interview with Dewi Herlina, S.Pd, Well-performed teacher 1 on 28 July 2019 at SDN 5 Nagrikaler Purwakarta
} 
every Monday activity which is conducted to increase the sense of nationalism is the Red and White flag ceremony activitie and the use of proper and correct Bahasa Indonesia.

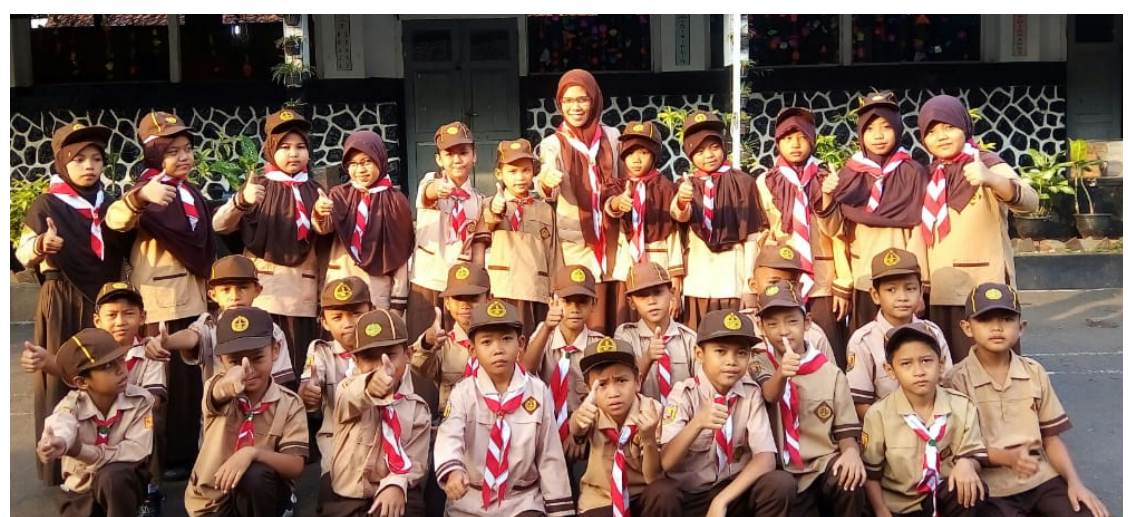

Fig. 1. Scout Uniform for Monday, Ajeg Nusantara.

\subsubsection{Tuesday, Mapag Buana}

Mapag means picking up, whereas Buana is the world. Literally, it means that education must always pick up an increasingly modern world civilization. One of the media used is internet. Students wear Red-White clothing while the teachers use Khaki-colored daily official clothing $(\mathrm{PDH})$. It is hoped that by using these clothes, the identity of the Indonesian people will always be attached even though they already know the outside world. Not only knowing about modern world civilization, students are also equipped with knowledge to know foreign cultures. One of the mandatory subjects on Tuesday is English.

"By knowing that there are cultural differences around the world, students will be able to distinguish and compare with the culture of their own country whether foreign culture can be implemented in Indonesia or not". ${ }^{3}$

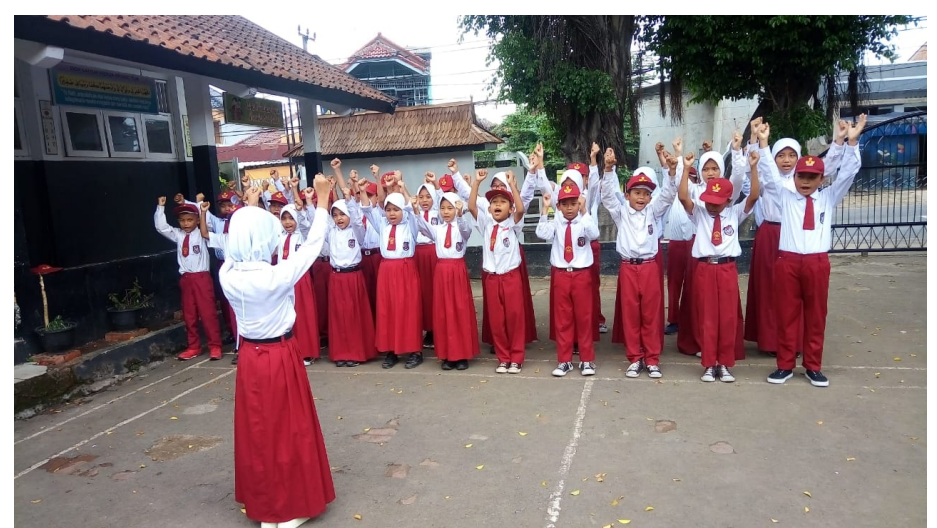

Fig. 2. Red-White Uniform for Tuesday, Mapag Buana.

\footnotetext{
${ }^{3}$ Interview with Uud Abdul Raup, S.Pd, Well-performed teacher 2, on 28 July 2019 at SDN 8 Ciseureuh, Purwakarta
} 


\subsubsection{Wednesday, Maneuh di Sunda}

The purpose of Maneuh di Sunda is to live in Sundanese region. Of course, as one of the regencies in West Java Province which is dominant with Sundanese culture, it is clear that every human being in Purwakarta must know his identity as a Sundanese. They must know their ancestors and they must know how Sundanese culture itself is. The clothes used in this educational environment are Sundanese clothing. Black Pangsi shirts for men, while women use kebaya, as well as the teachers.

"Of course, to support the Maneuh in Sunda program, the use of Sundanese every Wednesday is very mandatory. In fact, it is not only language, we are also accustomed to the use of Sundanese cultural etiquette itself." ${ }^{4}$

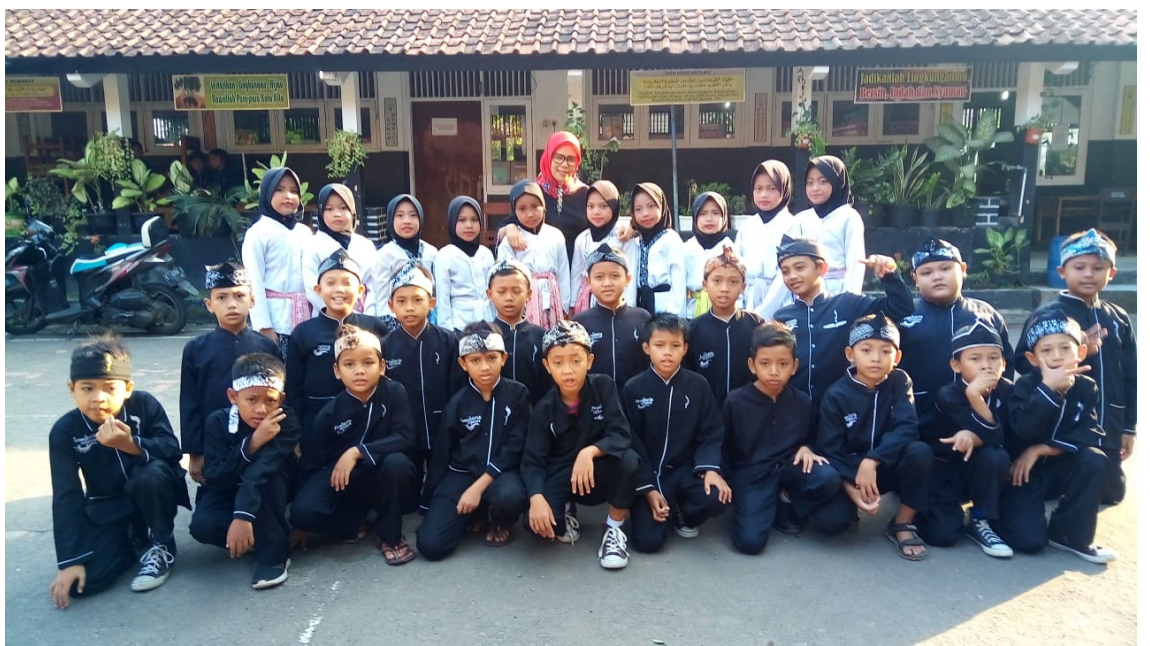

Fig. 3. Sundanese Clothing (Black Pangsi and Kebaya) for Wednesday, Maneuh di Sunda.

\subsubsection{Thursday, Nyanding Wawangi}

On Thursday, students are equipped with knowledge about how they create art, introduce art, and explore their creative abilities. On Thursday students and teachers wear batik as a form of appreciation for traditional art in Indonesia.

"On Thursday, we familiarize children with beauty or aesthetics, such as neatly dressing, organizing classes, and being polite". 5

As a "creative day", students are given the freedom to determine their imagination in various works of art such as drawing, writing poetry, singing, dancing, and making other handicrafts that are adapted to the learning theme of the week. Although the students are freed in creating, but the teacher's role as a supervisor cannot be simply separated.

${ }^{4}$ Interview with Dewi Herlina, S.Pd, Well-performed teacher 1 on 28 July 2019 at SDN 5 Nagrikaler Purwakarta

${ }^{5}$ Interview with Yulianti, S.Pd, Well-performed teacher 3 on 29 July 2019 at SDN 2 Nagrikaler Purwakarta 


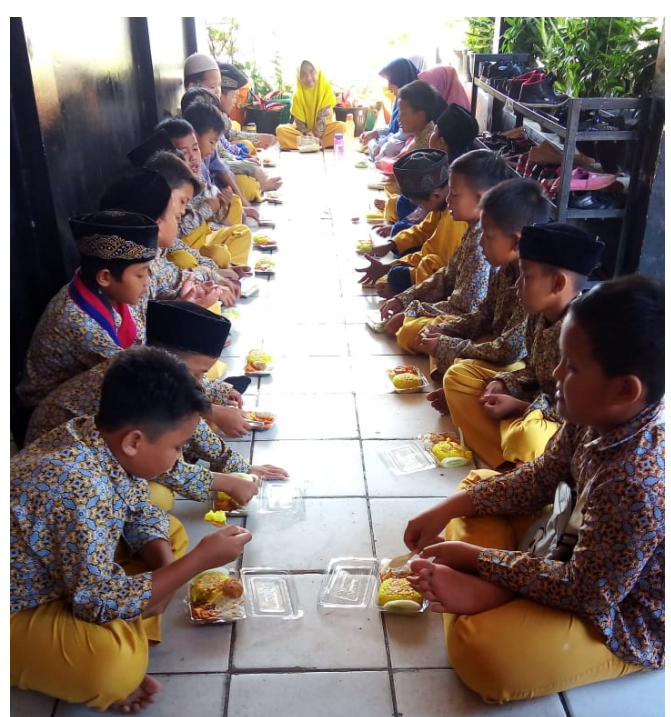

Fig. 4. Batik Uniform for Thursday, Nyanding Wawangi.

\subsubsection{Friday, Nyucikeun Diri}

Nyucikeun Diri means self-purifying or delivering oneself to the holiness. Sanctity here has the context of purity of heart or mind, soul and mind of every human being to stay awake and close to his Lord. The clothes used on Friday are koko clothes for teachers and male students, while for teachers and female students using Muslim clothing such as the robe.

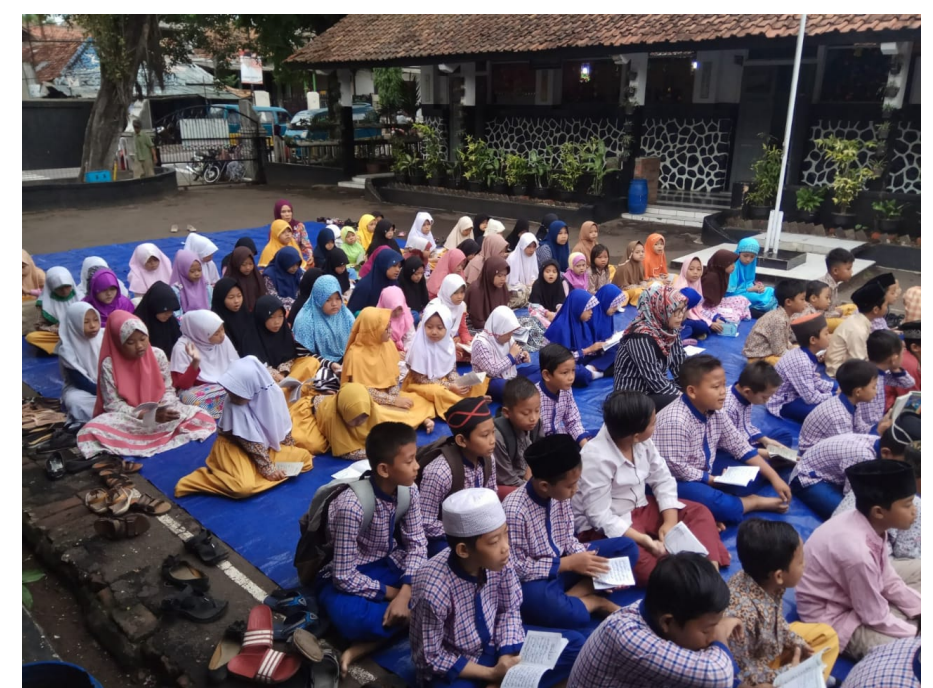

Fig. 5. Koko and Muslim Clothing for Friday, Nyucikeun Diri

"The practice of self-purifying can be done in various ways, in general because the majority are Muslim, so every Friday those who do Islam carry out the activities of 
reciting together in the school field, as well as Dhuha prayer guided by religious teachers. Whereas, non-Muslim students may adjust". ${ }^{6}$

For non-Muslim students, they usually read religious books provided by the Church or read story books provided by the school. They are accompanied by the student teacher of each school. Thus, there is no sense of intolerance in the school. In addition to self-purifying on a religious level, students and teachers also carry out Friday Clean activities. This cleaning activity is carried out in the school yard up to the sidewalk in front of the school, approximately 100 meters. The collaboration between the teachers and students is able to build responsibility where the cleanliness is part of the faith.

\subsubsection{Saturday and Sunday, Betah di Imah}

On Saturday and Sunday, the students learn at home. The teachers do not give any assignments to thr students. They are expected to feel at home with their parents to do activities together. This activity is usually called vocational activity. The students must follow the activities carried out by their parents at home. Thus, the students are able to appreciate the time to gather and know how their parents work for income.

"Betah di Imah does not mean they are on vacation, but they learn from daily life in their home environment whom their parents become direct teachers for this vocational. Sometimes on several occasions, their teachers also visit students' homes directly to find out how they communicate with their families"?

Students can again understand the basics of good and pre-existing values from the past with the 7 Days of Education. If this Sundanese culture is explored and re-instilled inherently through the learning of 7 Days of Character Education, it can be said that it is a movement on the basis of its own cultural values. In addition to forming students based on Sundanese values, this program is also used as an effort to build the national identity.

Table 1. Tipification of the 7 Days of Education Character Communication

\begin{tabular}{|c|l|l|l|}
\hline No & Day & Character Value & \multicolumn{1}{c|}{ Communication Form } \\
\hline 1 & Monday & Ajeg Nusantara & $\begin{array}{l}\text { - Non-Verbal: Using scout clothing, Red and White } \\
\text { flag ceremony activitie } \\
\text { - Verbal: the use of proper and correct Bahasa } \\
\text { Indonesia. }\end{array}$ \\
\hline 2 & Tuesday & Mapag Buana & $\begin{array}{l}\text { - Non-Verbal: Students wear Red-White clothing } \\
\text { while the teachers use Khaki-colored daily official } \\
\text { clothing (PDH) } \\
\text { - Verbal: Bahasa Indonesia, English }\end{array}$ \\
\hline 3 & Wednesday & Maneuh di Sunda & $\begin{array}{l}\text { - Verbal: The Use of Sundanese } \\
\text { - Non-Verbal: Sundanese clothing. Black Pangsi } \\
\text { shirts for men, while women use kebaya, as well as } \\
\text { the teachers }\end{array}$ \\
\hline
\end{tabular}

\footnotetext{
${ }^{6}$ Interview with Dewi Herlina, S.Pd, Well-performed teacher 1 on 28 July 2019 at SDN 5 Nagrikaler Purwakarta

${ }^{7}$ Interview with Head of Basic Education Division, Education Office, Purwakarta Regency on 29 Juli 2019 at Education Office, Purwakarta Regency
} 


\begin{tabular}{|c|c|c|c|}
\hline 4 & Thursday & $\begin{array}{l}\text { Nyanding } \\
\text { Wawangi }\end{array}$ & $\begin{array}{l}\text { - Non-Verbal: Students and teachers wear batik as a } \\
\text { form of appreciation for traditional art in Indonesia, } \\
\text { drawing, dancing, and making other handicrafts } \\
\text { - Verbal: Bahasa Indonesia, Singing }\end{array}$ \\
\hline 5 & Friday & Nyucikeun Diri & $\begin{array}{l}\text { - Verbal: Bahasa Indonesia, reciting together in the } \\
\text { school field, as well as Dhuha prayer. Whereas, non- } \\
\text { Muslim students may adjust. } \\
\text { - Non-Verbal: koko clothes for teachers and male } \\
\text { students, while for teachers and female students } \\
\text { using Muslim clothing such as the robe. Friday Clean } \\
\text { activities. }\end{array}$ \\
\hline 6 & $\begin{array}{l}\text { Saturday } \\
\text { and Sunday }\end{array}$ & Betah di Imah & $\begin{array}{l}\text { - Non-Verbal: Their parents become direct teachers } \\
\text { for this vocational. } \\
\text { - Verbal: Daily Language (Bahasa Indonesia, } \\
\text { Sundanese) }\end{array}$ \\
\hline
\end{tabular}

In implementing the 7 Days of Education character communication, there are of course various obstacles that occur in the field faced by the teachers. Some of the obstacles that usually occur in the 7 Days of Education program are as follows:

a) On Monday, there are still the students who have not yet used scout clothing in full, such as handkerchief, berets/hats, belts and others. Cultivating the attitude or spirit of patriotism is quite difficult because it is only done in school, whereas in the home environment, it is not formed properly because the family and environment are less supportive to build the soul of patriotism.

b) On Tuesday, the teacher's ability to speak English is one of the common obstacles because remembering that this Tuesday, students are brought to explore various information about other countries' cultures and also other knowledge related to these foreign cultures.

c) On Wednesday, the obstacle that occur is that not all students communicate using Sundanese in their home environment, so this also affects the use of language in the school environment.

d) On Thursday, building creativity and maintaining beauty (aesthetics) in clothing (for example) is still very difficult because they are not accustomed to doing it in the home environment. The process of building a creative soul and maintaining beauty is very long.

e) On Friday, even in religious activities, there are still many students who do not really focus and prefer to interact with their colleagues because the process of religious activities takes place simultaneously in the school yard or field.

Saturday and Sunday, the biggest obstacle in the 7 Days of Education are on this Saturday and Sunday. This is returned to each parent at home. Some of them do educate how the vocational activities go, while others allowed their children to play on those days.

\section{Conclusion}

The functions and objectives of 7 Days of Education program run straight with the local wisdom-based character education. It is also in line with the branding of Purwakarta Regency which upholds Sundanese culture. The 7 Days of Education program is communicated not only verbally, but also non-verbally, one of them is the uniforms that are used and also the habits that 
must be applied on a particular day. Although there are obstacles in the process of its implementation, the 7 Days of Education is well programmed. This program can shape the character of students in accordance with the philosophy of the nation and Sundanese culture.

\section{References}

[1] R. Pasaribu, Kebudayaan dan Masyarakat. Semarang: Universitas Dian Nuswantoro, 2015.

[2] M. Nuh, Menyemai Kreator Peradaban. Serambi Ilmu Semesta, 2013.

[3] L. J. Moleong, "Metodologi penelitian kualitatif (Cet. Ke-30.)," Bandung: Remaja Rosdakarya, 2012.

[4] M. P. P. Sugiyono and P. Kuantitatif, "Kualitatif, dan R\&D, Bandung: Alfabeta," Cet. VII, 2009.

[5] Kemendiknas, Buku Induk Pembangunan Karakter. Jakarta: Kementerian Pendidikan Nasional, 2010.

[6] J. M. Asmani, Buku panduan internalisasi pendidikan karakter di sekolah. Diva Press, 2011.

[7] Peraturan Bupati, Pendidikan Berkarakter No. 69 Pasal 5 ayat 2. Purwakarta. 2015.

[8] Bupati Purwakarta, LPKJ Bupati Purwakarta. 2012.

[9] T. Handayani, "Membangun Komunikasi Efektif Untuk Meningkatkan Kualitas Dalam Proses Belajar Mengajar," Ta'dib J. Islam. Educ. (Jurnal Pendidik. Islam., vol. 16, no. 02, pp. 273-302, 2011. 